\title{
GEOLOGY OF THE 241-U TANK FARM
}

by

W. H. Price

K. R. Fecht

Environmental Engineering Section Research Department

Research and Engineering Division

Apri1 1976

ATLANTIC RICHFIELD HANFORD COMPANY RICHLAND, WASHINGTON 99352

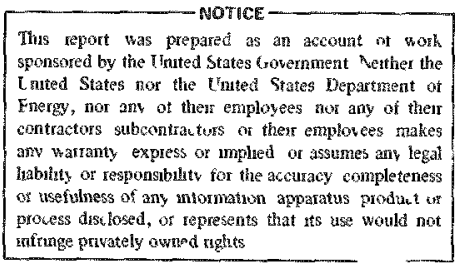




\section{DISCLAIMER}

This report was prepared as an account of work sponsored by an agency of the United States Government. Neither the United States Government nor any agency Thereof, nor any of their employees, makes any warranty, express or implied, or assumes any legal liability or responsibility for the accuracy, completeness, or usefulness of any information, apparatus, product, or process disclosed, or represents that its use would not infringe privately owned rights. Reference herein to any specific commercial product, process, or service by trade name, trademark, manufacturer, or otherwise does not necessarily constitute or imply its endorsement, recommendation, or favoring by the United States Government or any agency thereof. The views and opinions of authors expressed herein do not necessarily state or reflect those of the United States Government or any agency thereof. 


\section{DISCLAIMER}

Portions of this document may be illegible in electronic image products. Images are produced from the best available original document. 
TABLE OF CONTENTS

Page

INTRODUCTION. PROCEDURES

GENERALIZED GEOLOGY

COLUMBIA RIVER BASALT GROUP .

RINGOLD FORMATION

Middle Ringold.

EOLIAN SILT DEPOSIT

CALICHE DEPOSITS.

GLACIOFLUVIAL DEPOSITS.

CLASTIC DIKES.

BACKFILL MATERIAL

WATER TABLE

GLOSSARY

SELECTED REFERENCES

LIST OF TABLES

Table

Page

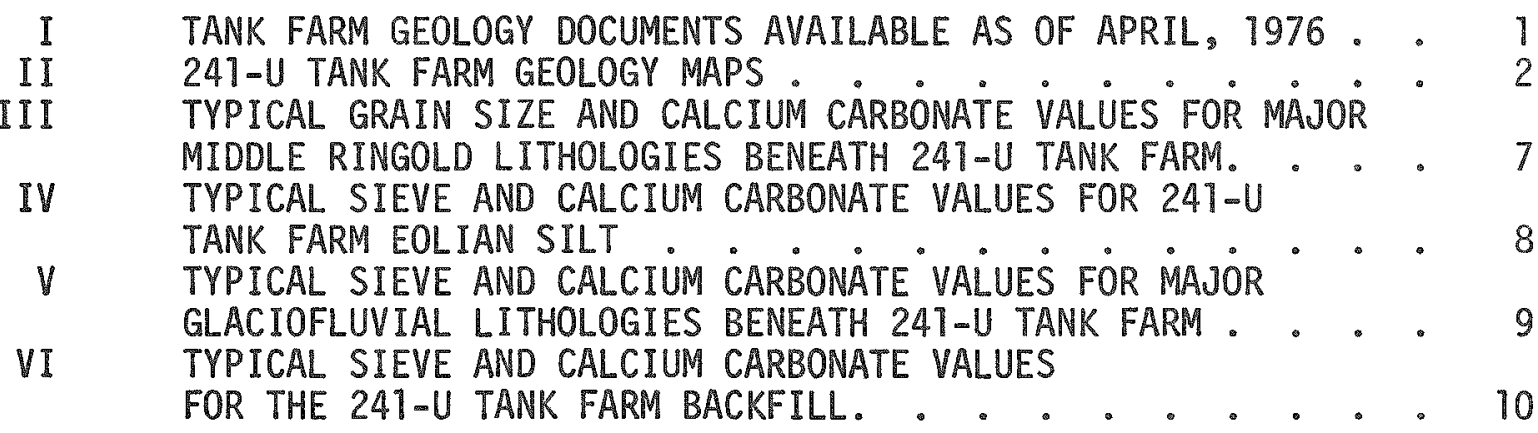




\section{LIST OF FIGURES}

Figure

Page

1 STEPS OUTLINING THE PREPARATION OF TANK

2 GARM GEOLOGY MAPS. ${ }^{\circ}$ GENERIZED STRATIGRAPHIC COLUMN FOR THE 200 AREA TANK FARMS . . . . . . . . . . . 5 


\section{INTRODUCTION}

A series of maps have been compiled to document the structure and stratigraphy of the sediments underlying the high-level radioactive waste storage tank farms located within the Energy Research and Development Administration Hanford Reservation. The primary purpose of these maps is to provide basic geologic information to be utilized to evaluate the impact of suspected and confirmed tank leaks. For convenience of usage map sets for each tank farm have been published in separate document packets (see Table I). The contents of this packet (see Table II) contain maps compiled only for the 247-U Tank Farm.

TABLE I

TANK FARM GEOLOGY DOCUMENTS AVAILABLE AS OF APRIL, 1976*

\begin{tabular}{|c|c|}
\hline Title & $\begin{array}{l}\text { Document } \\
\text { Number }\end{array}$ \\
\hline Geology of the 241-A Tank Farm & ARH-LD-127 \\
\hline Geology of the 247-AX Tank Farm & ARH-LD-128 \\
\hline Geology of the 241-B Tank Farm & ARH-LD-129 \\
\hline Geology of the 241-BX Tank Farm & ARH-LD-130 \\
\hline Geology of the 241-BY Tank Farm & ARH-LD-131 \\
\hline Geology of the 241-C Tank Farm & ARH-LD -132 \\
\hline Geology of the 241-S Tank Farm & ARH-LD-133 \\
\hline Geology of the 241-SX Tank Farm & ARH-LD-134 \\
\hline Geology of the 241-T Tank Farm & ARH-LD-135 \\
\hline Geology of the 241-TX Tank Farm & ARH-LD-136 \\
\hline Geology of the 241-TY Tank Farm & ARH-LD-137 \\
\hline Geology of the 241-U Tank Farm & ARH-LD-138 \\
\hline $\begin{array}{l}\text { Generalized Geology of the } \\
241-S Y \text { Tank Farm }\end{array}$ & ARH-LD-139 \\
\hline
\end{tabular}




\section{TABLE II}

241-U TANK FARM GEOLOGY MAPS

247-U Tank Farm Geologic Map Legend and Plot Plan

$H-2-38990$

241-U Tank Farm Geologic Characterization Cross Section A-A'

H-2-38959

241-U Tank Farm Geologic Characterization Cross Section $B-B^{\prime}$

$\mathrm{H}-2-38960$

241-U Tank Farm Geologic Characterization Cross Section $\mathrm{C}-\mathrm{C}^{\prime}$

$H-2-38961$

241-U Tank Farm Geologic Characterization Cross Section $D-D^{\prime}$

H-2-38962

241-U Tank Farm Geologic Characterization Cross Section E-E'

H-2-38963

247-U Tank Farm Geologic Characterization Cross Section F-F"

$\mathrm{H}-2-38964$

241-U Tank Farm Geologic Characterization Cross Section $G-G^{\prime}$

$H-2-38965$

241-U Tank Farm Geologic Characterization Cross Section $\mathrm{H}^{-\mathrm{H}^{\prime}}$

$\mathrm{H}-2-38966$

241-U Tank Farm Geologic Characterization Cross Section I-I'

$H-2-38967$

241-U Tank Farm Geologic Characterization Base of Backfill

$\mathrm{H}-2-38957$

241-U Tank Farm Geologic Characterization Paleotopography of Silt Horizon

$H-2-38958$ 


\section{PROCEDURES}

During the drilling of 40 dry wells and 2 water wells in and around the 241-U Tank Farm, sediment samples were collected from one to 5-foot depth intervals. Information utilized to prepare this series of maps was obtained by the analysis of these samples, numbering approximately 1300 .

Each sediment sample was quantitatively analyzed according to grain size and $\mathrm{CaCO}_{3}$ content. Size analys is was carried out utilizing a nest of 9 sieves selected for coincidence with the Wentworth (1922) grain size nomenclature (see $\mathrm{H}-2-38990$ ). The $\mathrm{CaCO}_{3}$ content of each sample was determined utilizing a semiquantitative $\mathrm{CO}_{2}$ displacement method (Horwitz, 1970). Size and $\mathrm{CaCO}_{3}$ data was input into the Rocksan Computer Program (Parr, 1974) which categorized each sediment sample into 1 of 19 classes (classification scheme modified after Folk, 1968; see H-2-38990). After analysis, each sample was visually examined to aid in further characterization. Each sample was subsequently stored in the Hanford Well Library for future reference. For convenience of usage, the geologic maps were prepared at the same scale $\left(1^{\prime \prime}=16^{\prime}\right)$ as drawing $\mathrm{H}-2-36948$ (We11s in 241-U Farm As-bui1t). Steps outlining the preparation of the maps are listed in Figure 1.

\section{GENERALIZED GEOLOGY}

Included within this section is a brief discussion of the geology underlying the 241-U Tank Farm. The stratigraphic descriptions included, along with the Glossary (see page 11), are designed only to provide sufficient information to permit a general understanding of the Tank Farm maps presented. For a more detailed discussion of the regional geologic setting of the 241-U Tank Farm, the reader is referred to articles listed in the Selected References (see page 13).

The 241-U Tank Farm is underlain by four major stratigraphic units (see Figure 2): (1) basalt of the Columbia River Group which forms the bedrock beneath the area; (2) semiconsolidated sediments of the Ringold Formation which directly overlie the bedrock; (3) unconsolidated eolian silt; and 


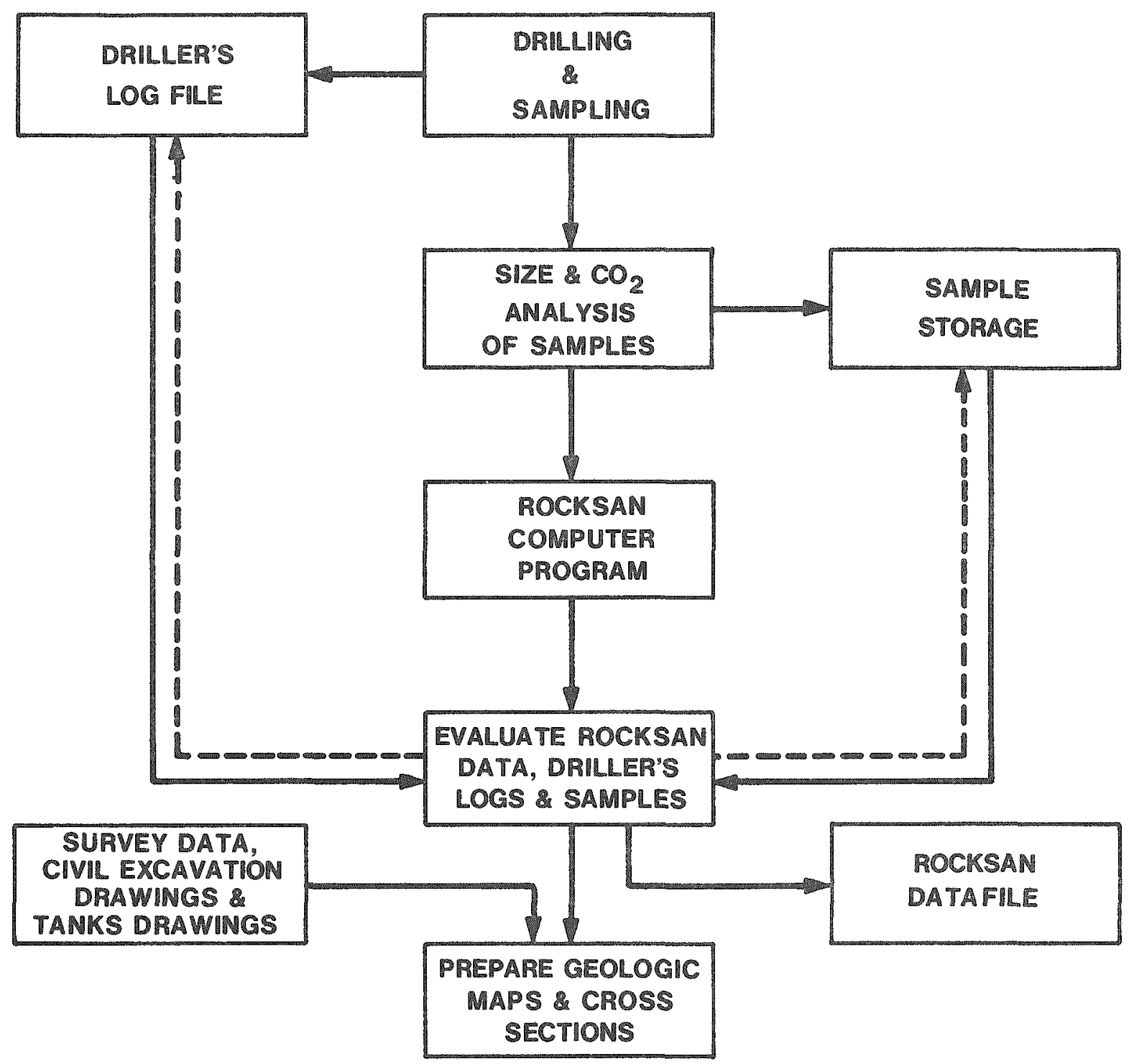

FIGURE 1

STEPS OUTLINING THE PREPARATION OF TANK FARM GEOLOGY MAPS 


\begin{tabular}{|c|c|c|c|c|c|c|}
\hline 通 & $\frac{8}{\frac{0}{8 \pi}}$ & EPOCH & YEARS B. P. & \multicolumn{2}{|c|}{$\begin{array}{l}\text { STRATIGRAPHIC } \\
\text { NAME AND/OR } \\
\text { UNIT }\end{array}$} & LITHOLOGY DESCRIPTION \\
\hline \multirow{8}{*}{$\begin{array}{l}0 \\
0 \\
0 \\
0 \\
0 \\
0 \\
0 \\
0\end{array}$} & \multirow{3}{*}{ 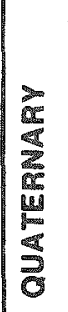 } & MOOERN & & & BACRFILL & VEPY POORLY SORTED GRAVEL, SAND \& SILT \\
\hline & & \multirow{2}{*}{ 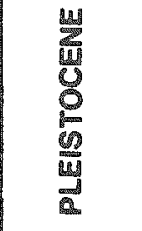 } & \multirow{4}{*}{\multicolumn{2}{|c|}{$1,000,000$}} & $\begin{array}{l}\text { ACIOFLUVIAL } \\
\text { EEDIMENTS }\end{array}$ & $\begin{array}{l}\text { FAIRLY WELL SORTED FLUVIAL SAND \& } \\
\text { SILT WITH SOME GRAVEL }\end{array}$ \\
\hline & & & & & OLIAN SILT & $\begin{array}{l}\text { FINE SAND \& SILT DERIVED FROM THE } \\
\text { UPPER RINGOLD }\end{array}$ \\
\hline & \multirow{5}{*}{$\frac{t}{E}$} & \multirow{5}{*}{ 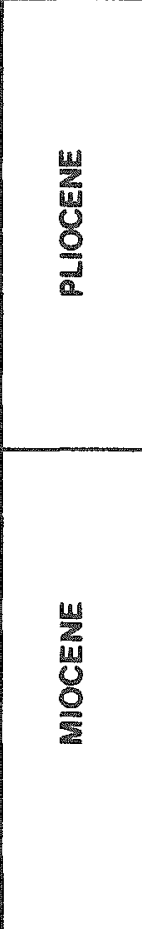 } & & & $\begin{array}{l}\text { UPPEP } \\
\text { RINGOLD }\end{array}$ & $\begin{array}{l}\text { WELL SORTEO FLUVIAL OR LACUSTRINE } \\
\text { SILT \& SAND WITH SOME CALCAREOUS } \\
\text { LAYERS }\end{array}$ \\
\hline & & & & & $\begin{array}{l}\text { MIDDLE } \\
\text { PINGOLD }\end{array}$ & $\begin{array}{l}\text { FLUVIAL GRAVEL \& SAND VARIABLY } \\
\text { CEMENTED WITH CALCIUM CARBONATE \& } \\
\text { SILICA }\end{array}$ \\
\hline & & & \multirow[t]{3}{*}{$11,000,000$} & \multirow{3}{*}{ 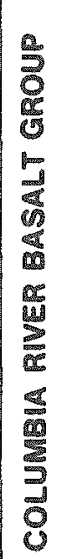 } & $\begin{array}{l}\text { ELEPHANT } \\
\text { MOUNTAIN } \\
\text { MEMBER }\end{array}$ & $\begin{array}{l}\text { DENSE BLACK EXTRUSIVE IGNEOUS ROCK, } \\
\text { MRCRO VESICULAR, BRICK BAT } \\
\text { ENTABULATURE \& NO COLUMNADE }\end{array}$ \\
\hline & & & & & $\begin{array}{l}\text { RATTLESNAKE } \\
\text { RIDGE } \\
\text { MEMBER }\end{array}$ & TUFFACEOUS SANDSTONE \\
\hline & & & & & $\begin{array}{l}\text { POMONA } \\
\text { MEMBER }\end{array}$ & $\begin{array}{l}\text { DENSE BLACK EXTRUSIVE IGNEOUS ROCK, } \\
\text { SCATTERED OLIVINE PHENOCRYSTS, } \\
\text { UPPER \& SOMETIMES BASAL ENTABLATURE } \\
\text { WELL DEVELOPED, FAN JOINTING IN } \\
\text { COLUMNADE }\end{array}$ \\
\hline
\end{tabular}

WHP/KRF 1976

\section{FIGURE 2}

GENERALIZED STRATIGRAPHIC COLUMN FOR

THE 200 AREA TANK FARMS 
(4) unconsolidated sand, silt, and gravel, collectively termed glaciofluvial sediments, which directly overlie the eolian silt. A more detailed description of the character of these units underlying the Tank Farm follows.

\section{COLUMBIA RIVER BASALT GROUP}

About 20 million years ago a series of fissures opened around the periphery of the subsiding Pasco Basin and large volumes of basaltic lava poured out over the land surface. The highly fluid lava was extruded intermittently from these fissures until approximately 8 million years ago. At the cessation of Columbia River Basalt volcanism, the basin had been filled with more than 12,000 feet of basalt.

The surface of the Columbia River Basalt lies beneath 241-U Vank Farm at an elevation of 127 feet (a11 elevations based on feet above mean sea level measured at approximate center of Tank Farm). On the 241-U Tank Farm maps, this surface occurs approximately 233 feet below the bottom border of the prepared cross sections.

\section{RINGOLD FORMATION}

Following the cessation of Columbia River Basalt volcanism the ancestral Columbia River transported sediments from the surrounding highlands into the Pasco Basin where they accumulated to form the Ringold Formation. Beneath the Hanford Reservation, this formation is up to 1200 feet thick and can generally be divided into three units on the basis of lithology; the clays and silts of the lower Ringold unit; the pebbles and cobbles of the middle Ringold unit; and the silts and fine sands of the upper Ringold unit.

Within the region beneath 241-U Tank Farm, the lower and upper Ringold units are missing. The total thickness of the Ringold Formation present is approximately 399 feet. 
Middle Ringold

Beneath the 241-U Tank Farm, the 399-foot thick middle Ringold unit lies unconformably on the Columbia River Basalt and dips to the southeast about 50 feet per mile. The unit consists predominantly of well-rounded pebbles and cobbles with the interstitial spaces filled with medium to fine sand and silt cemented in places with $\mathrm{SiO}_{2}$ or $\mathrm{CaCO}_{3}$. Table III summarizes the grain size and $\mathrm{CaCO}_{3}$ values of the middle Ringold sediments.

\section{TABLE III}

TYPICAL GRAIN SIZE AND CALCIUM CARBONATE VALUES

FOR MAJOR MIDDLE RINGOLD LITHOLOGIES BENEATH 241-U TANK FARM

\begin{tabular}{|c|c|c|c|c|c|c|c|c|}
\hline \multirow[b]{2}{*}{ Lithology } & \multirow[b]{2}{*}{$\begin{array}{r}\text { \%Pebbles } \\
\text { \& Cobbles } \\
\end{array}$} & \multicolumn{5}{|c|}{$\%$ Sand } & \multirow[b]{2}{*}{$\begin{array}{r}\text { \% Silt } \\
\text { clay } \\
\end{array}$} & \multirow[b]{2}{*}{${ }^{2} \mathrm{CaCO}_{3}$} \\
\hline & & $\begin{array}{l}\text { Very } \\
\text { Coarse } \\
\end{array}$ & Coarse & Medium & Fine & $\begin{array}{l}\text { Very } \\
\text { Fine } \\
\end{array}$ & & \\
\hline Sandy Gravel & 77 & 2 & 3 & 4 & 9 & 5 & 1 & 0.3 \\
\hline $\begin{array}{l}\text { Cemented Calcareous } \\
\text { to Siliceous } \\
\text { Siightly Silty } \\
\text { Sandy Gravel }\end{array}$ & 70 & 4 & 6 & 6 & 8 & 5 & 1 & $0-12.0$ \\
\hline $\begin{array}{l}\text { Coarse to } \\
\text { Medium Sand }\end{array}$ & 2 & 11 & 25 & 29 & 15 & 11 & 7 & 1.0 \\
\hline $\begin{array}{l}\text { Slighty Cemented } \\
\text { Calcareous to } \\
\text { Siliceous } \\
\text { Slightly silty } \\
\text { Sand Gravel }\end{array}$ & 72 & 4 & 5 & 6 & 7 & 5 & 1 & $0-12.0$ \\
\hline $\begin{array}{l}\text { Coarse to } \\
\text { Medium Sand }\end{array}$ & 1 & 9 & 26 & 36 & 15 & 10 & 4 & 1.0 \\
\hline $\begin{array}{l}\text { Cemented Calcareous } \\
\text { to Siliceous } \\
\text { Siighity Silty } \\
\text { Sandy Gravel }\end{array}$ & 67 & 8 & 7 & 6 & 6 & 5 & 1 & $0-12.0$ \\
\hline
\end{tabular}


In contrast, sediments of the middle Ringold unit above the 233-foot elevation level have undergone oxidation as evidenced by their gray-brown color and their well developed weathering rinds.

Although the middle Ringold unit consists predominantly of pebbles and cobbles, a few sand units up to 17 feet in thickness occur beneath 200 West Area. Such units represent either lacustrine or fluvial deposits layed down during periods of decreased velocity of the ancestral Columbia River. Two such units are found beneath the 241-U Tank Farm at elevations of 378 feet and 398 feet.

\section{EOLIAN SILT DEPOSIT}

After deposition of the Ringold Formation, the surface of the land was subjected to subaerial erosion. Wind action winnowed, reworked, and redeposited the fine grained sands and silts of the nearby upper Ringold unit. These wind-deposited sediments, termed Early Palouse soil or eolian silt, occur beneath the 241-U Tank Farm between elevations 526 and 546 feet. After deposition of the eolian silt, the climate was arid as indicated by $\mathrm{CaCO}_{3}$ (caliche) found within the unit. Table IV summarizes the grain size and $\mathrm{CaCO}_{3}$ content of the eolian silt.

\section{TABLE IV}

TYPICAL SIEVE AND CALCIUM CARBONATE VALUES FOR 241-U TANK FARM EOLIAN SILT

\begin{tabular}{|c|c|c|c|c|c|c|c|c|}
\hline \multirow[b]{2}{*}{ Lithology } & \multirow[b]{2}{*}{$\begin{array}{r}\text { \%Pebbles } \\
\text { \& Cobbles } \\
\end{array}$} & \multicolumn{5}{|c|}{ \% Sand } & \multirow[b]{2}{*}{$\begin{array}{r}\% \text { Silt } \\
\text { Clay } \\
\end{array}$} & \multirow[b]{2}{*}{$\% \mathrm{CaCO}_{3}$} \\
\hline & & $\begin{array}{l}\text { Very } \\
\text { Coarse }\end{array}$ & Coarse & Medium & Fine & $\begin{array}{l}\text { Very } \\
\text { Fine }\end{array}$ & & \\
\hline $\begin{array}{l}\text { Calcareous Sandy } \\
\text { Silt to Silty } \\
\text { Very Fine Sand }\end{array}$ & 0 & 0 & 1 & 9 & 19 & 33 & 38 & 11.0 \\
\hline ACIOFLUVIAL & TS & & & & & & & \\
\hline
\end{tabular}

During the close of the Ice Age, approximately 20,000 years ago, a continental ice sheet covered much of northern Washington. As the ice sheet retreated northward, the breakup of ice dams resulted in catastrophic floods in which large volumes of glacial meltwater were released. 
During one of these floods, over 500 cubic miles of water is estimated to have poured into the Pasco Basin at a rate of more than 9 cubic miles of water per hour. Sediments deposited within the basin by such flooding now comprise the glaciofluvial unit. The characteristic variability of sediment size and degree of sorting within this unit can be attributed to changes in water velocity and water level which occurred during the flooding process.

Glaciofluvial deposits are found beneath the 241-U Tank Farm between elevations 546 and 626 feet. The 80-foot thick section of these deposits consists predominently of coarse to fine sand with some silt and pebbles. Table $V$ summarizes the grain size and $\mathrm{CaCO}_{3}$ values of the glaciofluvial sediments.

\section{TABLE V}

TYPICAL SIEVE AND CALCIUM CARBONATE VALUES

FOR MAJOR GLACIOFLUVIAL LITHOLOGIES

BENEATH 247-U TANK FARM

\begin{tabular}{|c|c|c|c|c|c|c|c|c|}
\hline \multirow[b]{2}{*}{ Lithology } & \multirow[b]{2}{*}{$\begin{array}{r}\text { \%pebbles } \\
\text { \& Cobbles } \\
\end{array}$} & \multicolumn{5}{|c|}{ \% Sand } & \multirow[b]{2}{*}{$\begin{array}{r}\text { \%silt } \\
\text { \& Clay } \\
\end{array}$} & \multirow[b]{2}{*}{$\mathrm{daCO}_{3}$} \\
\hline & & $\begin{array}{l}\text { Very } \\
\text { Coarse } \\
\end{array}$ & Coarse & Medium & Fine & $\begin{array}{l}\text { Very } \\
\text { Fine } \\
\end{array}$ & & \\
\hline $\begin{array}{l}\text { Silty Sandy Medium } \\
\text { to Very Fine Pebble } \\
\text { to Pebbly Very } \\
\text { Coarse to Coarse } \\
\text { Sand }\end{array}$ & 35 & 15 & 13 & 9 & 7 & 5 & 11 & 2.0 \\
\hline $\begin{array}{l}\text { Sightly Silty } \\
\text { Coarse to Fine } \\
\text { Sand to Coarse } \\
\text { to Fine Sand }\end{array}$ & 3 & 8 & 19 & 20 & 23 & 15 & 12 & 1.9 \\
\hline $\begin{array}{l}\text { Slightiy Silty } \\
\text { Medium to Very } \\
\text { Fine Sand to } \\
\text { Silty Mediun to } \\
\text { Very Fine Sand }\end{array}$ & 0 & 5 & 15 & 21 & 25 & 19 & 15 & 1.7 \\
\hline
\end{tabular}

\section{CLASTIC DIKES}

Throughout the Pasco Basin, clastic dikes are found cross-cutting the Ringold Formation and glaciofluvial sediments. These dikes, which range from a few inches to several feet in width, are known to exist to depths of more than 100 feet below the ground surface. Generally, the dikes are 
composed of fine silts to coarse sands. The origin of the clastic dikes is still in refute and will not be discussed here (see Selected References). Identification of clastic dikes by drilling is difficult and although some dikes were detected in the 241-U Tank Farm, they could not be mapped.

\section{BACKFILL MATERIAL}

In preparation for tank construction, glaciofluvial material was excavated at the 241-U Tank Farm site. This material, consisting predominantly of cobbles, pebbles, and coarse to medium sands to silts, was subsequently used as backfill from the base of the completed tanks (626 feet) to the ground surface ( 665 feet). An inherent characteristic of the backfill is its poor sorting. Grain size and $\mathrm{CaCO}_{3}$ values for the backfill are found in Table VI.

\section{TABLE VI}

TYPICAL SIEVE AND CALCIUM CARBONATE VALUES FOR THE 24T-U TANK FARM BACKFILL

\begin{tabular}{|c|c|c|c|c|c|c|c|c|}
\hline \multirow[b]{2}{*}{ Lithology } & \multirow[b]{2}{*}{$\begin{array}{l}\text { \%Pebbles } \\
\text { Cobbles } \\
\end{array}$} & \multicolumn{5}{|c|}{$\%$ Sand } & \multirow[b]{2}{*}{$\begin{array}{r}\text { \%5ilt } \\
\text { a clay } \\
\end{array}$} & \multirow[b]{2}{*}{$\mathrm{\% CaCO}_{3}$} \\
\hline & & $\begin{array}{l}\text { Very } \\
\text { Coarse }\end{array}$ & Coarse & Medium & Fine & $\begin{array}{l}\text { Very } \\
\text { Fine } \\
\end{array}$ & & \\
\hline $\begin{array}{l}\text { Silty Sandy Medium } \\
\text { to Very Fine Pebble }\end{array}$ & 35 & 10 & 11 & 12 & 12 & 10 & 10 & 2.1 \\
\hline
\end{tabular}

\section{WATER TABLE}

The water table beneath the 241-U Tank Farm is located within the middle Ringold unit at an elevation of 483 feet, 143 feet below the base of the tanks. For further information concerning contours on the water table beneath 200 West Area the reader is referred to drawings $\mathrm{H}-2-38397$ (200 West Area Water Table Map) and H-2-38877 (200 West Area Depth to Water Map). 


\section{GLOSSARY}

Basalt. Fine-grained, dark-colored, extrusive igneous rock.

Calcareous. Containing calcium carbonate.

Caliche. Gravel, sand, or silt cemented by calcium carbonate.

Cement. Chemically precipitated material occurring in the interstices between particles of gravel, sand, or silt.

Clastic. A textural term applied to rocks composed of fragmental material derived from pre-existing rocks.

Clastic dike. A tabular body of clastic material transecting the bedding of a sedimentary formation, representing extraneous material that has invaded the containing formation along a crack.

Dip. The angle at which a stratum or any planar feature is inclined from the horizontal.

Eolian. A formation formed by, or deposited from, the wind or currents of air.

Fluvial. Produced by the action of a river or stream.

Formation. The ordinary unit of geologic mapping consisting of a large and persistent stratum of some one kind of rock.

Glaciofluvial. Pertaining to streams flowing from glaciers or to the deposits made by such streams.

Grain. The particles or discrete crystals which comprise a rock or sediment.

Group. A local or provincial subdivision of a series, based on lithologic features and contains two or more formations.

Lacustrine. A formation deposited in a lake environment.

Lava. Fluid rock such as that which issues from a volcano or a fissure in the earth's surface and the same material solidified by cooling.

Lithology. The description of rocks or sediments on the basis of such characteristics as color, minerologic composition and grain size.

Sediment. Descriptive term for grave1, sand, and silt transported from their sources and deposited by air, water, or ice.

Sieve. A utensil having many small perforated openings, used to separate fine particles from coarser ones. 
Siliceous. Containing silica.

Silt. Fine grained material between sand and clay in size.

Sorting. The grain size range of the sediments.

Stratigraphy. The part of descriptive geology of an area that pertains to the discrimination, character, thickness, sequence, age and correlation of the sediments and rocks of the area.

Subaerial. Formed, existing, or taking place on the land surface.

Unconformity. A surface of erosion or nondeposition that separates younger strata from older strata.

Water table. The upper surface of a zone of saturation except where that surface is formed by an impermeable body.

Winnowing. Separation of fine particles from coarser ones by wind action. 


\section{SELECTED REFERENCES}

1. J. A. Alwin, Clastic Dikes of Touchet Beds, Southeastern Washington, Washington State University Masters Thes is (1970).

2. V.R. Baker, Paleohydrology and Sedimentology of Lake Missoula Flooding in Eastern Washington, Geological Society of America Special Paper 144, (1973).

3. J. H. Bretz, Washington's Channeled Scabland, Washington Division of Mines and Geology, Bu17. 45, (1959).

4. D. J. Brown, Subsurface Geology of the Hanford Separations Areas, HW-61780 (1959).

5. D. J. Brown, An Eolian Deposit Beneath 200 West Area, HW-67549 (1960).

6. D. J. Brown, and R. E. Brown, Touchet Clastic Dikes in the Ringold Formation, HW-SA-2851 (1962).

7. D. J. Brown, G. T. Lobde11, and G. E. Neff, Hydrology and Engineering Geology of the Columbia Basin, Geological Society of America, Cordilleran Section, 72nd Annual Meeting, Field Guide No. 3 (1976).

8. R. L. Folk, "Petrology of Sedimentary Rocks," University of Texas Press (1968).

9. R. Fryxe11, and E. F. Cook, A Field Guide to the Loess Deposits and Channeled Scablands of the Palouse Area, Eastern Washington, Laboratory of Anthropology Report 27, Pu17man, Washington (1964).

10. E. H. Gilmour, and D. Stradiing, Proceedings of the Second Columbia River Basalt Symposium, EWSC Press, Cheney, Washington (1969).

11. E. Gustafson, A Revised Chronology for Vertebrate Fossil Faunas of Eastern Washington, Geological Society of America, Cordit7eran Section, 72nd Annual Meeting (1976).

12. W. Horwitz, Official Methods of Analysis of the Association of Official Analytical Chemists, 11th Edition, Association of Official Analytical Chemists, p. 139, (1970).

13. R. K. Ledgerwood, D. J. Brown, C. W. Meyers, and A. C. Waters, Identification of Yakima Basalt Flows in the Pasco Basin, ARH-27-68 (1973).

14. R. L. Lupher, Clastic Dikes of the Columbia Basin Region, Washington and Idaho, Geological Society of America BuT1., V55, 1437-1462 (1944). 
15. M. W. McGoniea, Deformation of the Ringold Formation, HW-36373 (1955).

16. B. McKee, Cascadia the Geologic Evolution of the Pacific Northwest, McGraw-Hil Took Co. (1972).

17. R. C. Newcomb, J. R. Strand, and F. J. Frank, Geology and Groundwater Characteristics of the Hanford Reservation of the U.S. Atomic Energy Commission, Washington, U.S. Geological Survey Prof. Paper 717 (1972).

18. J. M. Parr, Sieve Analys is Program, Atlantic Richfield Hanford Company, Unpublished.

19. G. D. Webster, V.R. Barber, and C. Gustafson, Channeled Scabland of Southeastern Washington A Road Log Via Spokane - Coulee City - Vantage Washtucna - Lewiston - Pullman, Geological Society of America, Cordilleran Section, 72nd Annual Meeting, Field Guide No. 2 (1976).

20. C. K. Wentworth, A Scale of Grade and Class Terms for Clastic Sediments, Je.urnal of Geology, V. 30, 377-392 (1922). 
Energy Research and Development

Administration - Richland Operations office

0.J. Elgert Fed 700

J.A. Fernandez Fed 700

A.G. Lasila Fed 700

Battelle-Northwest

R.L. Brodzinski

J.R. Eliason

V.L. McGhan

S.J. Phillips

J. Raymond

R.W. Wallace

Atlantic Richfield Hanford Company

B.W. Anderson

J. Anderson

H. Babad

G.E. Backman

L.D. Bockstanz

D.G. Bouse

D.J. Brown

L.E. Bruns

G. Burton, Jr.

R.A. Deju

F.R. Dornheim

G.T. Dukelow

P.G. Easley

K.R. Fecht

R.D. Fox

D.G. Harlow

W.M. Harty

O.F. Hill

H.F. Jensen

M.W. Legatski

B.J. McMurray

P.W. Metz

W.H. Price (2)

R.C. Roal

B.J. Saueressig

V.D. Schrag

H.P. Shaw

J.A. Teal

R.E. Van der Cook

R.L. Walser 


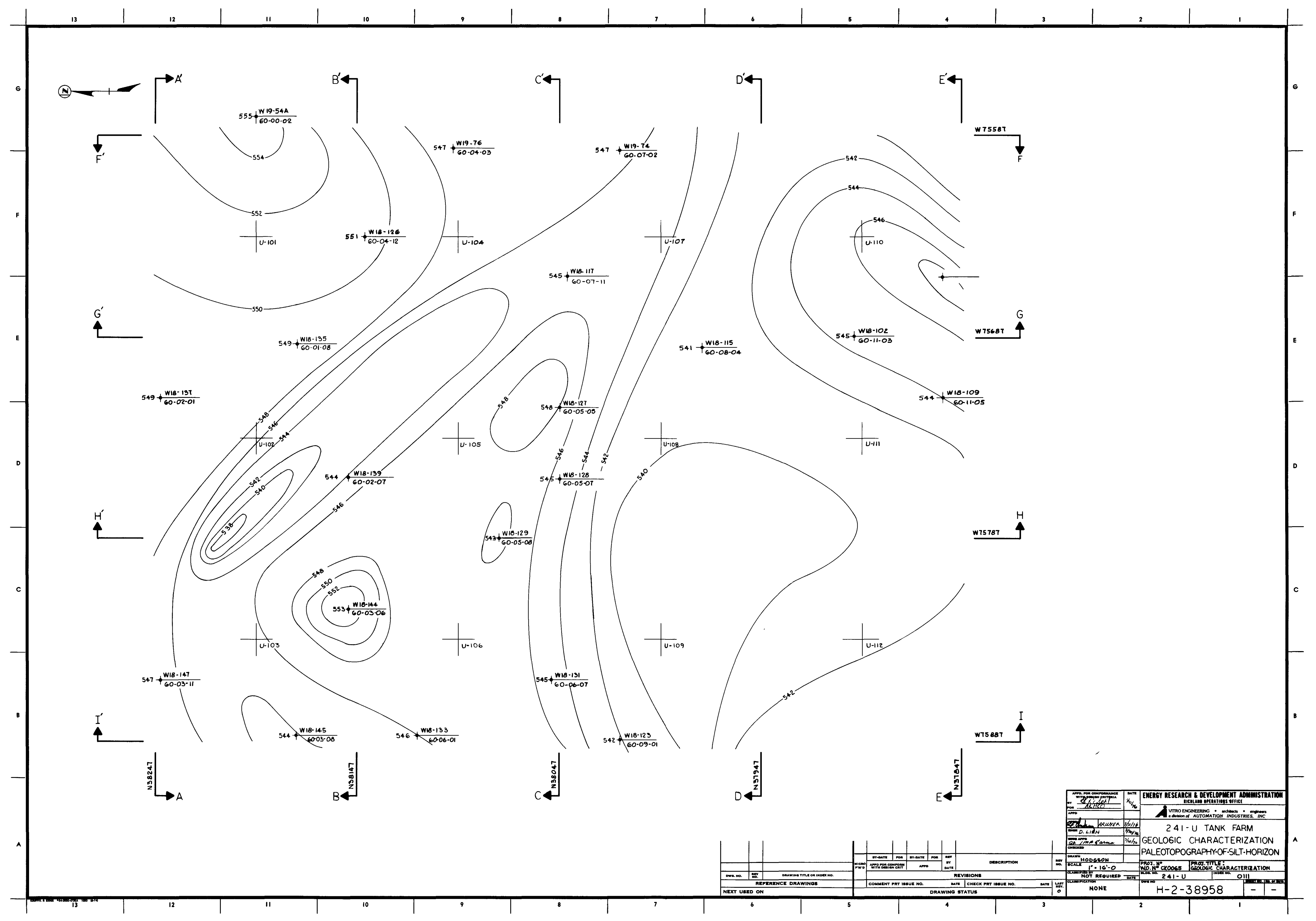




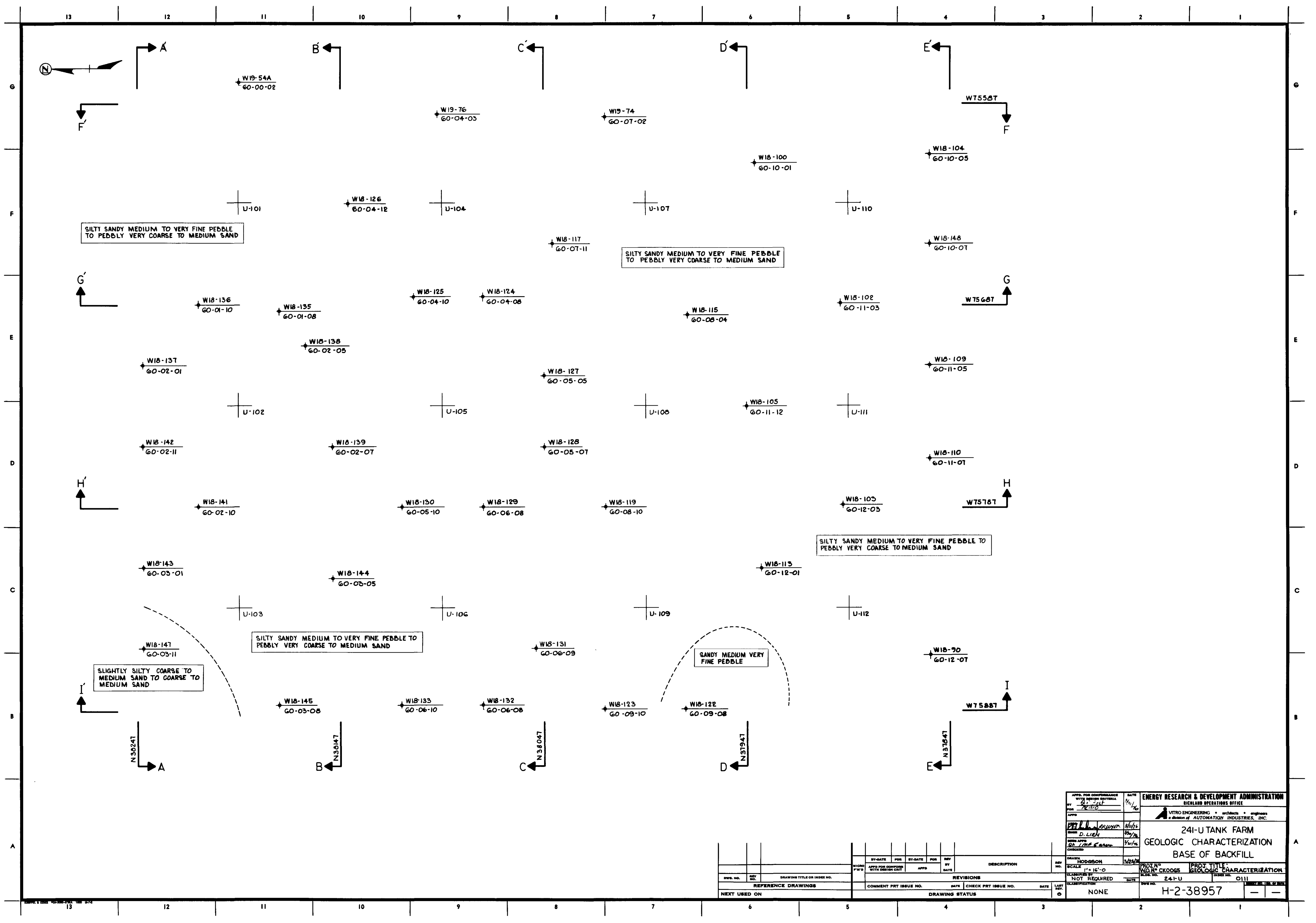




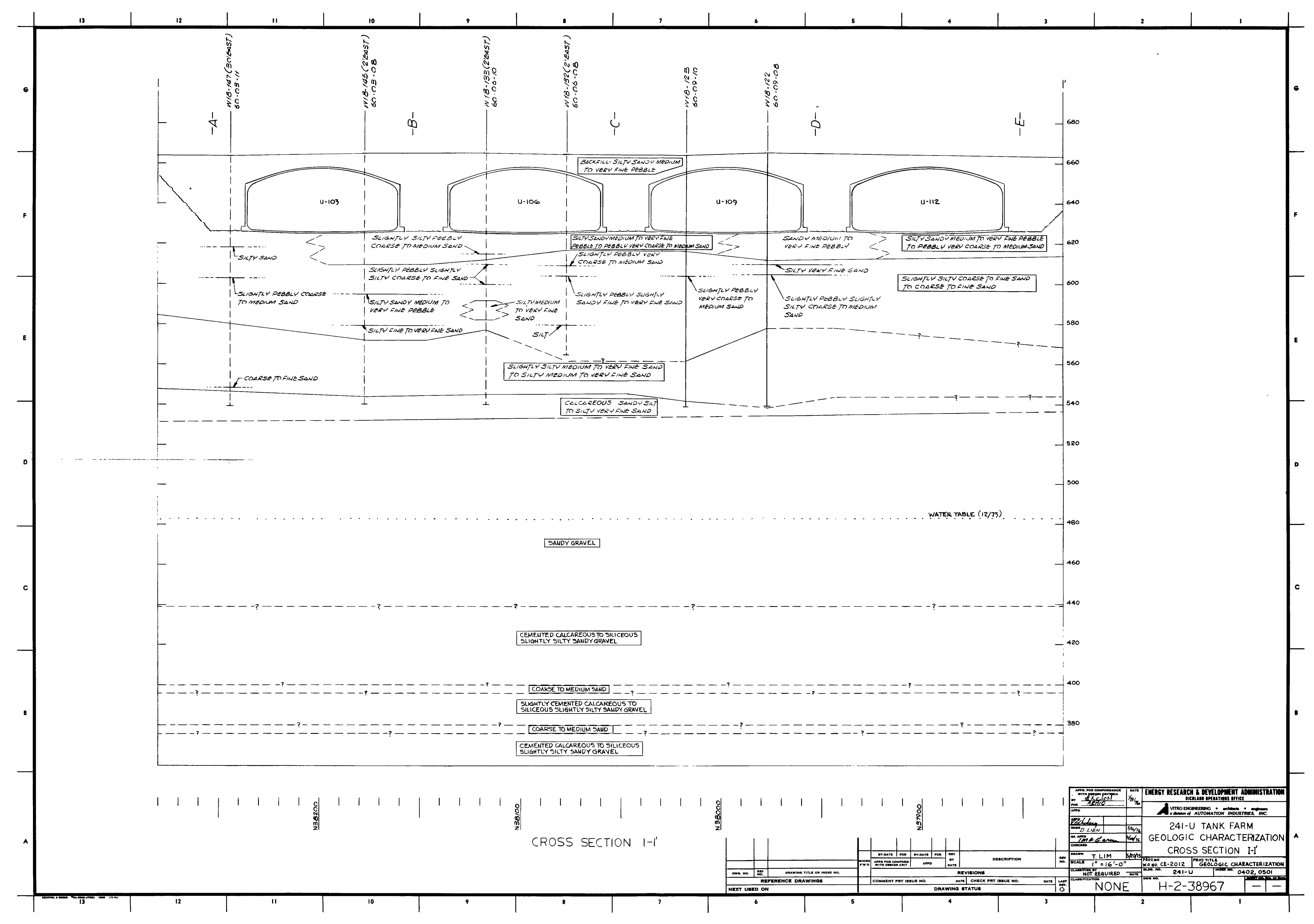




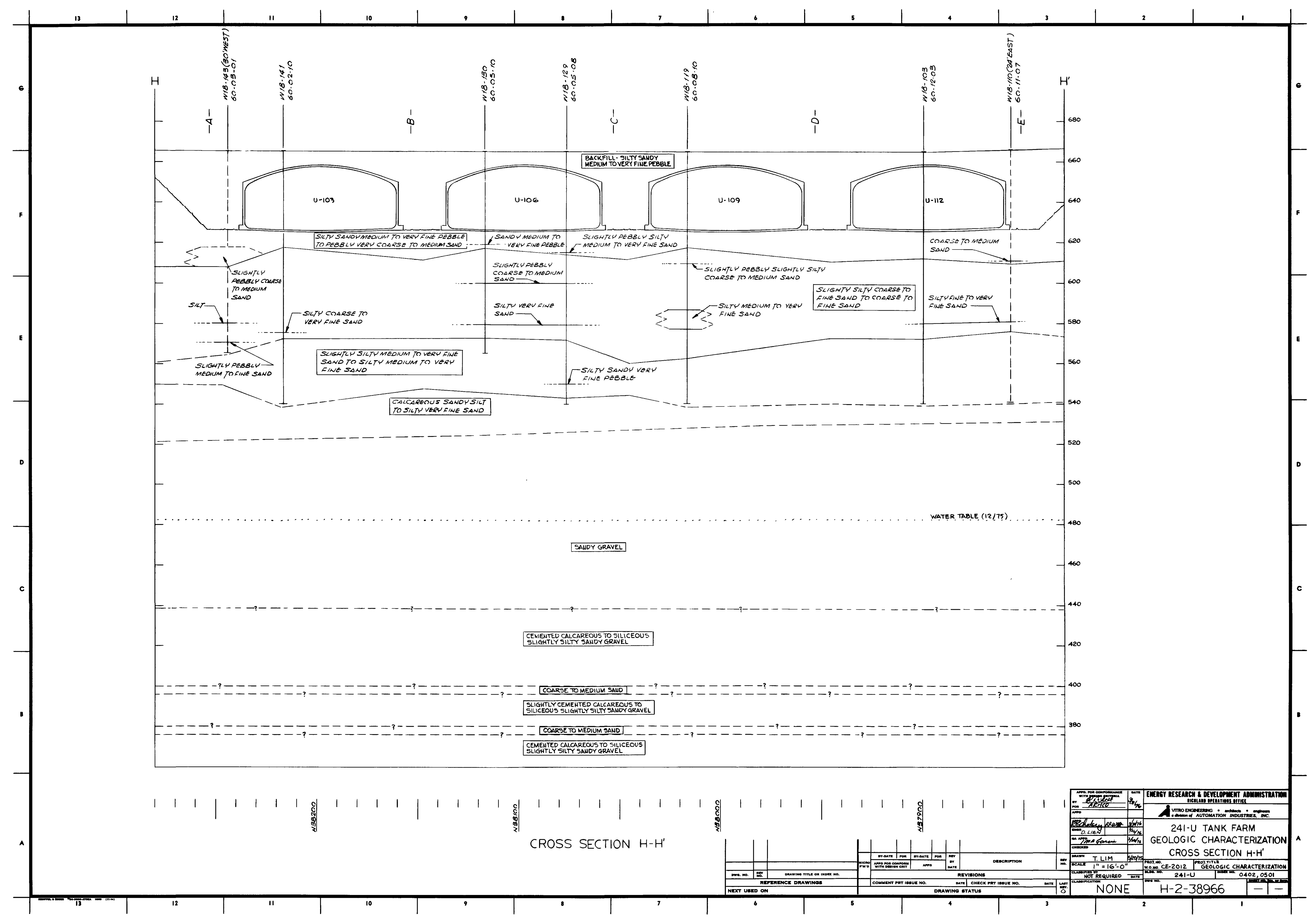




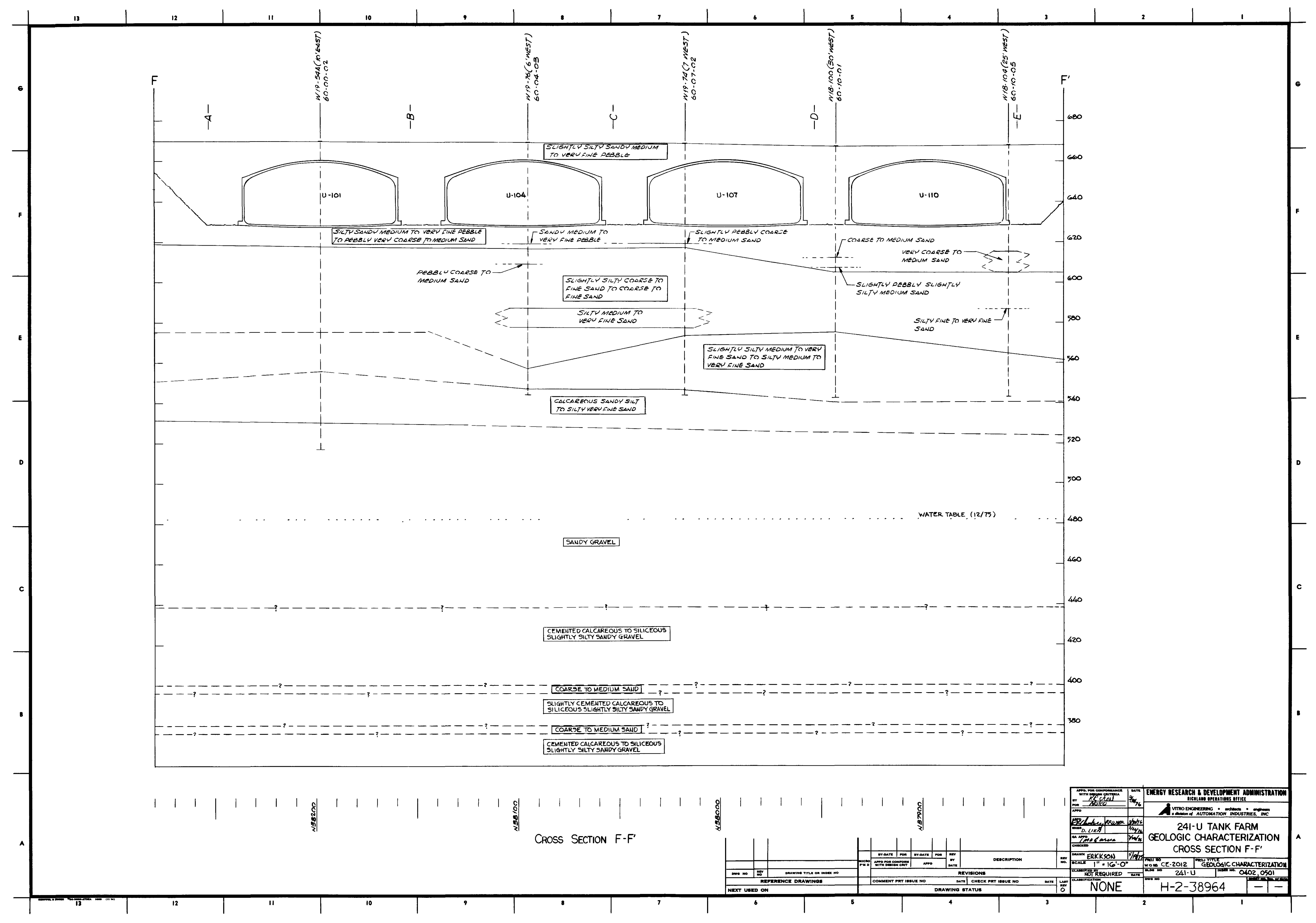




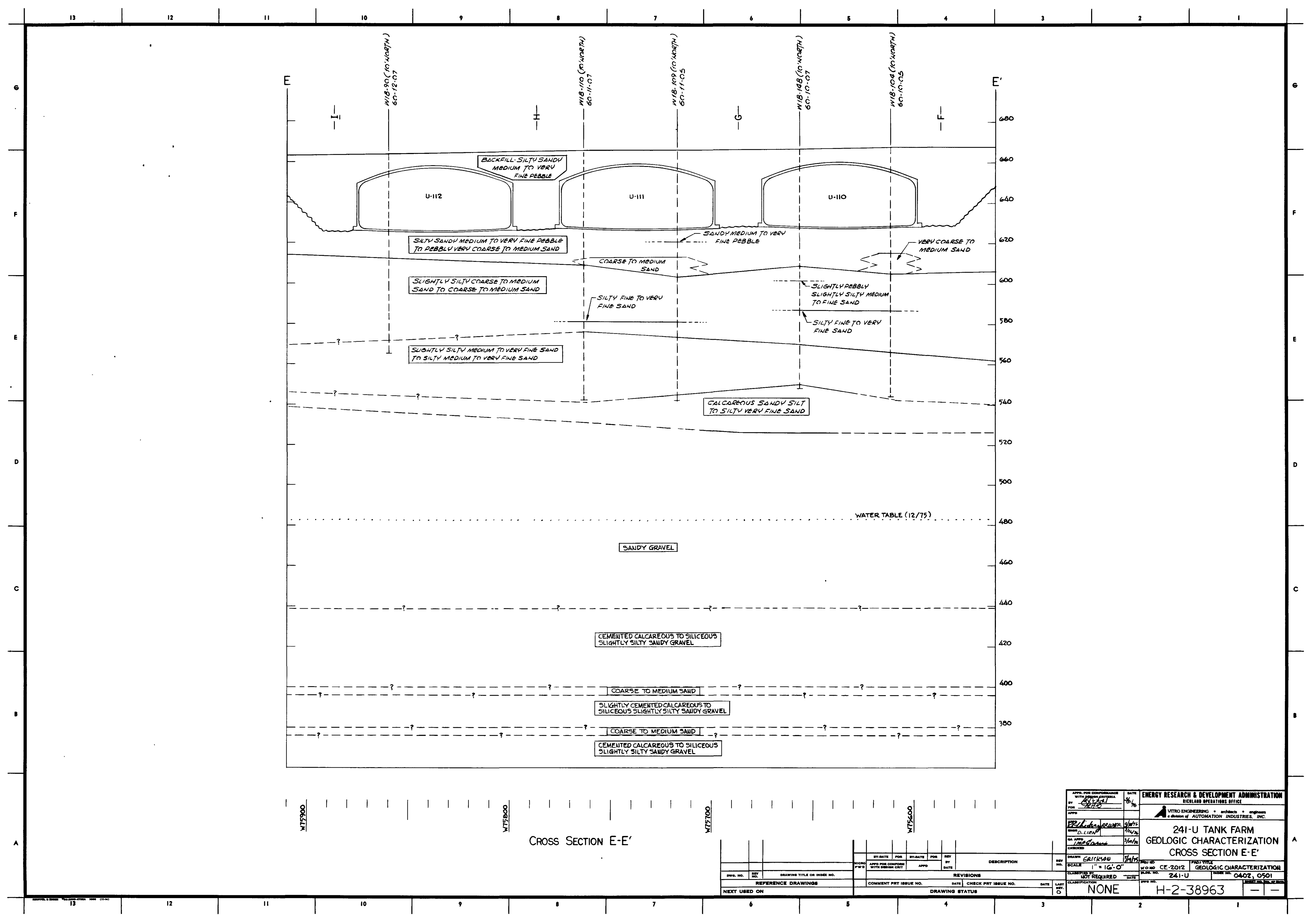




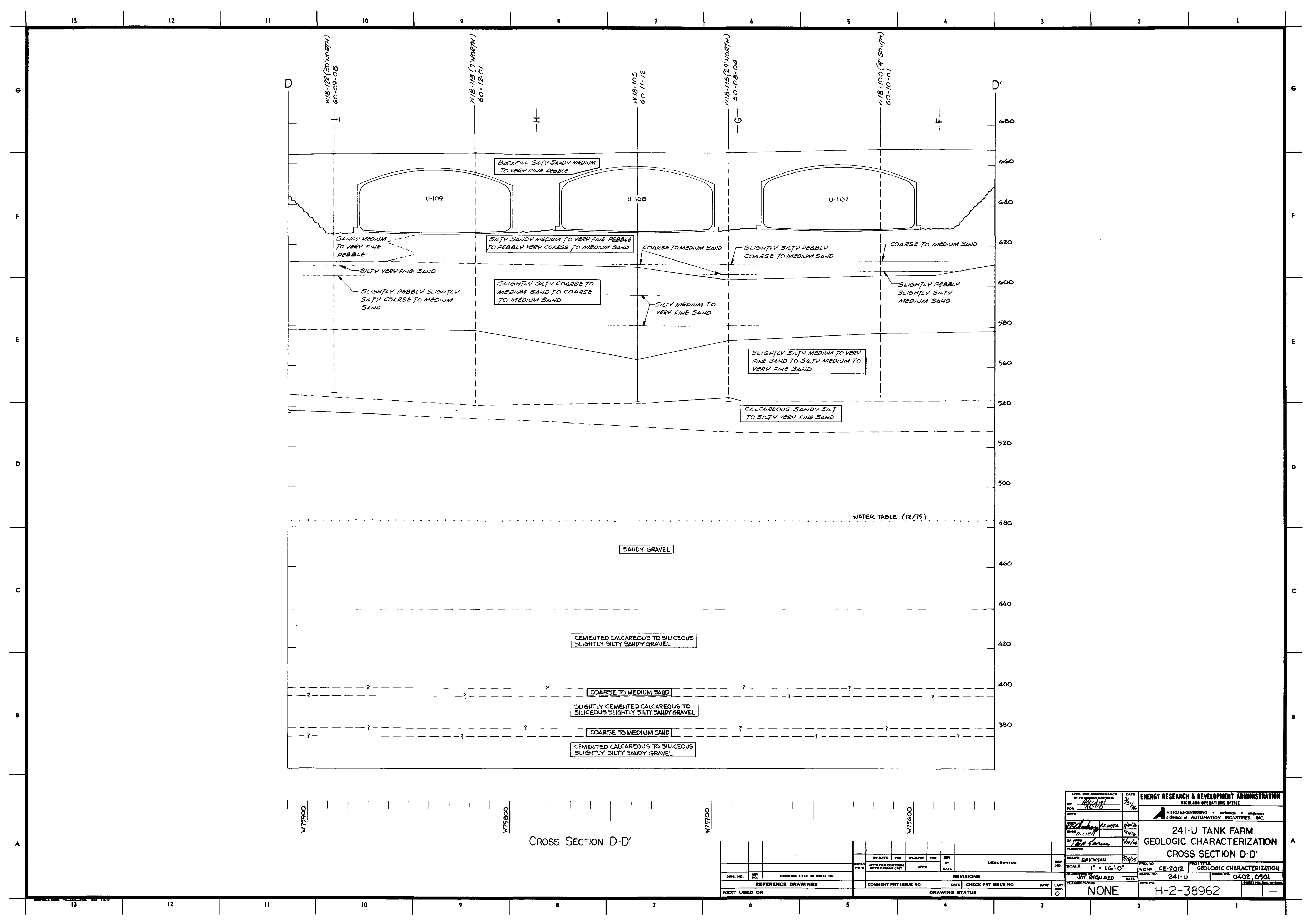




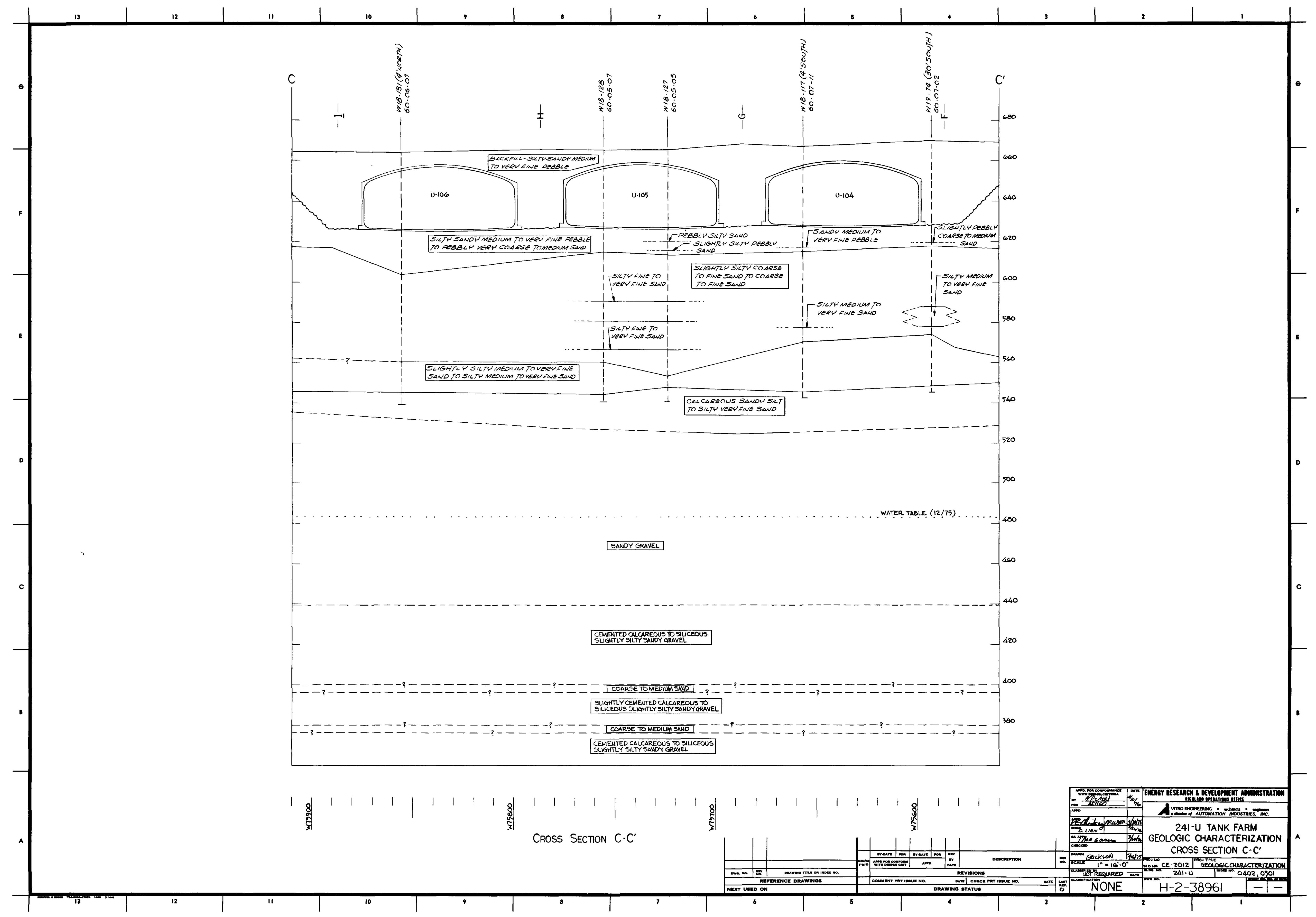




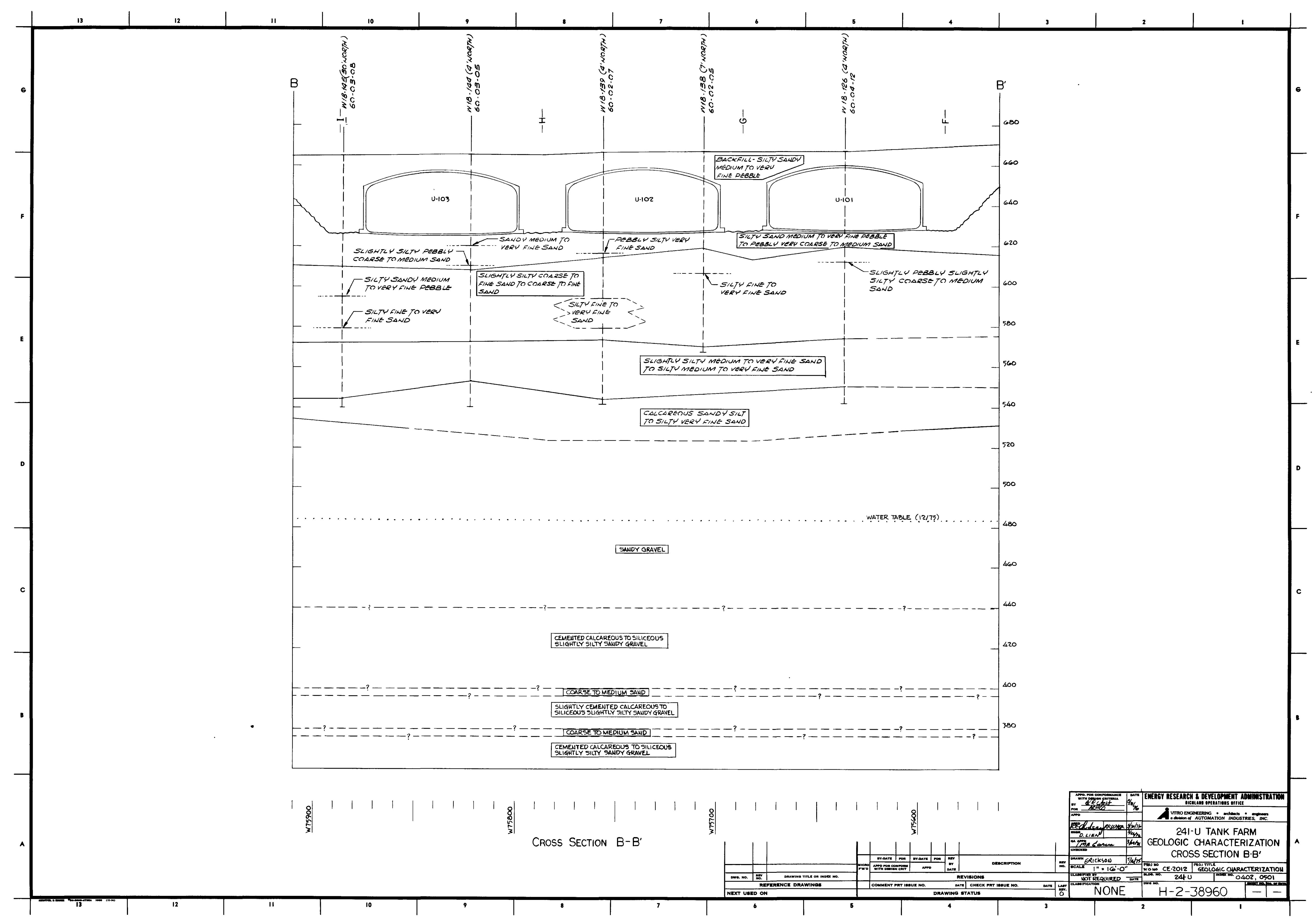




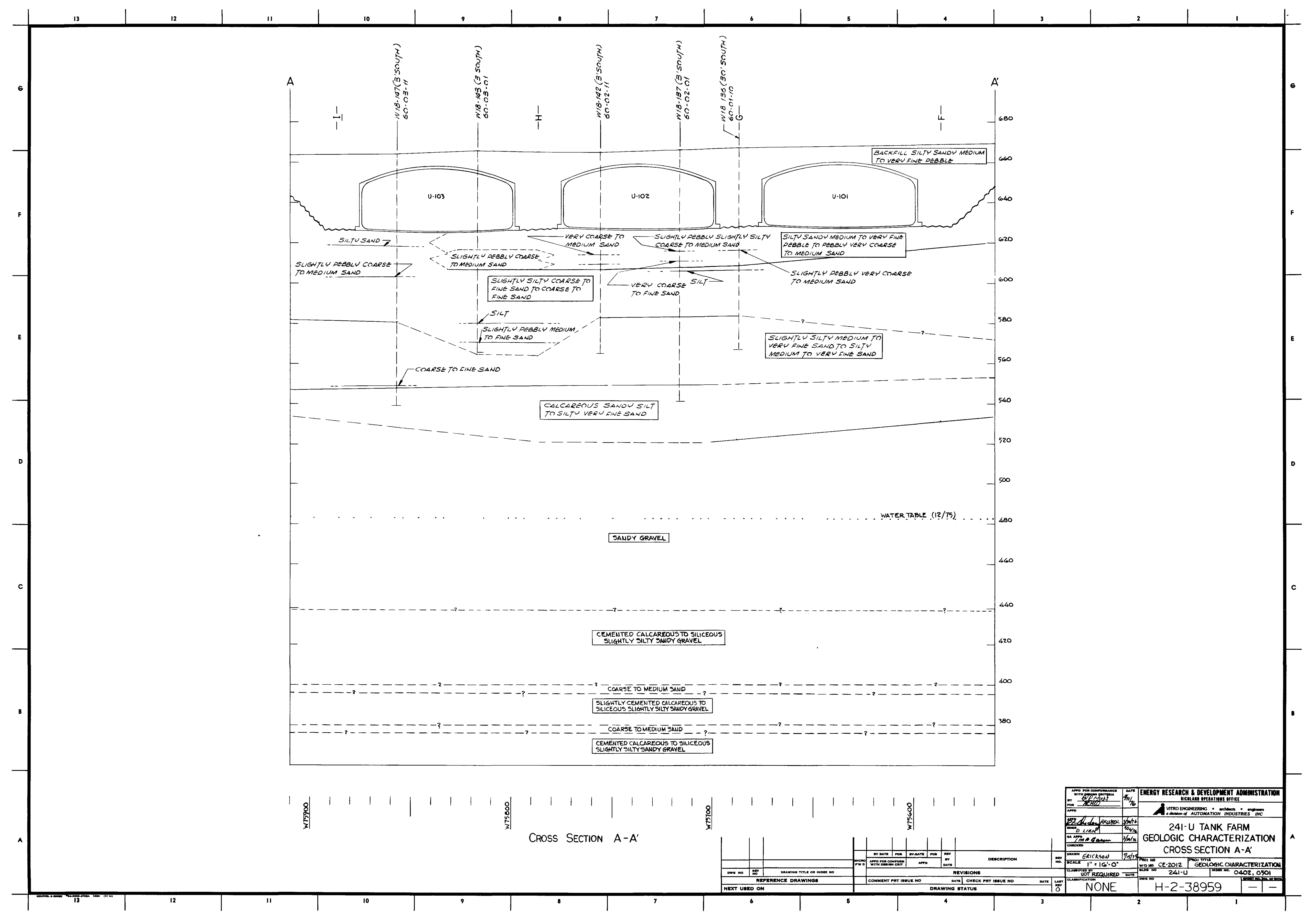




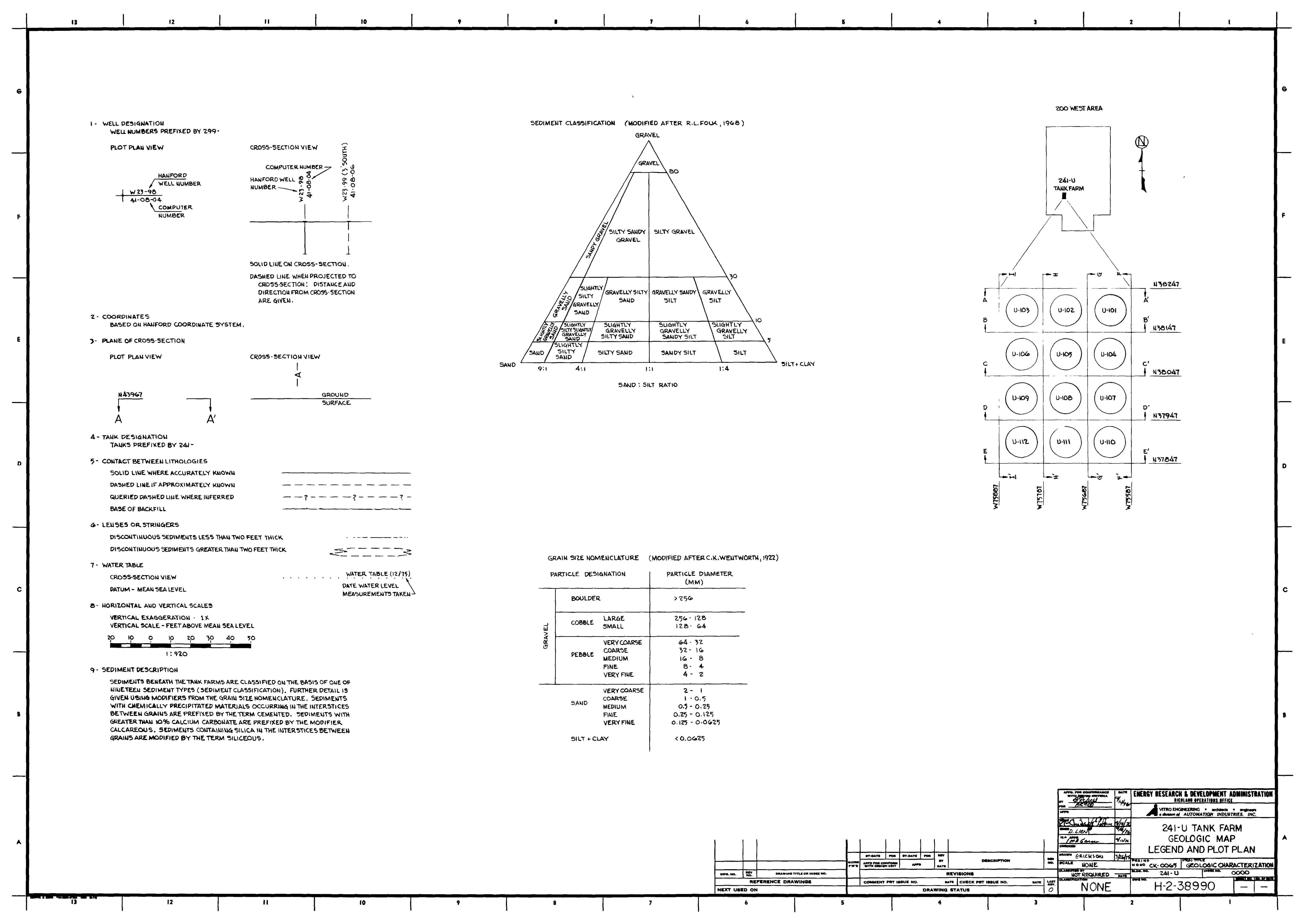

